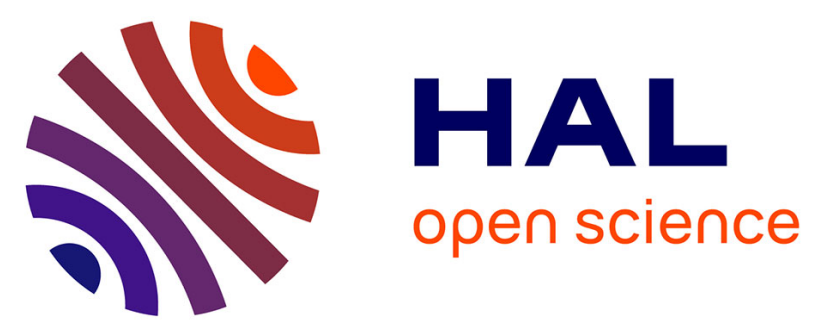

\title{
Degradation of Carbon-Supported Platinum-Group-Metal Electrocatalysts in Alkaline Media Studied by in Situ Fourier Transform Infrared Spectroscopy and Identical-Location Transmission Electron Microscopy
}

Clémence Lafforgue, Frédéric Maillard, Vincent Martin, Laetitia Dubau, Marian Chatenet

\section{- To cite this version:}

Clémence Lafforgue, Frédéric Maillard, Vincent Martin, Laetitia Dubau, Marian Chatenet. Degradation of Carbon-Supported Platinum-Group-Metal Electrocatalysts in Alkaline Media Studied by in Situ Fourier Transform Infrared Spectroscopy and Identical-Location Transmission Electron Microscopy. ACS Catalysis, 2019, 9 (6), pp.5613-5622. 10.1021/acscatal.9b00439 . hal-02334297

\author{
HAL Id: hal-02334297 \\ https://hal.science/hal-02334297
}

Submitted on 5 Nov 2019

HAL is a multi-disciplinary open access archive for the deposit and dissemination of scientific research documents, whether they are published or not. The documents may come from teaching and research institutions in France or abroad, or from public or private research centers.
L'archive ouverte pluridisciplinaire HAL, est destinée au dépôt et à la diffusion de documents scientifiques de niveau recherche, publiés ou non, émanant des établissements d'enseignement et de recherche français ou étrangers, des laboratoires publics ou privés. 
Article

Subscriber access provided by BIBCNRS INC

Degradation of Carbon-supported Platinum Group Metal Electrocatalysts in Alkaline Media Studied by in situ Fourier-Transform Infrared Spectroscopy and Identical-Location Transmission Electron Microscopy

Clémence Lafforgue, Frédéric Maillard, Vincent Martin, Laetitia Dubau, and Marian Chatenet ACS Catal., Just Accepted Manuscript • DOI: 10.1021/acscatal.9b00439 • Publication Date (Web): 10 May 2019

Downloaded from http://pubs.acs.org on May 11, 2019

\section{Just Accepted}

"Just Accepted" manuscripts have been peer-reviewed and accepted for publication. They are posted online prior to technical editing, formatting for publication and author proofing. The American Chemical Society provides "Just Accepted" as a service to the research community to expedite the dissemination of scientific material as soon as possible after acceptance. "Just Accepted" manuscripts appear in full in PDF format accompanied by an HTML abstract. "Just Accepted" manuscripts have been fully peer reviewed, but should not be considered the official version of record. They are citable by the Digital Object Identifier (DOIB). "Just Accepted" is an optional service offered to authors. Therefore, the "Just Accepted" Web site may not include all articles that will be published in the journal. After a manuscript is technically edited and formatted, it will be removed from the "Just Accepted" Web site and published as an ASAP article. Note that technical editing may introduce minor changes to the manuscript text and/or graphics which could affect content, and all legal disclaimers and ethical guidelines that apply to the journal pertain. ACS cannot be held responsible for errors or consequences arising from the use of information contained in these "Just Accepted" manuscripts. 


\title{
Degradation of Carbon-supported Platinum Group
}

\author{
Metal Electrocatalysts in Alkaline Media Studied by
}

in situ Fourier-Transform Infrared Spectroscopy and

Identical-Location Transmission Electron

\section{Microscopy}

\author{
Clémence Lafforgue ${ }^{l^{*}}$, Frédéric Maillard ${ }^{{ }^{*}}$, Vincent Martin ${ }^{1}$, Laetitia Dubau $^{l}$, Marian Chatenet $^{l^{*}}$ \\ ${ }^{1}$ Univ. Grenoble Alpes, Univ. Savoie Mont Blanc, CNRS, Grenoble INP, LEPMI, 38000 \\ Grenoble, France
}

\begin{abstract}
Alkaline fuel cells and electrolyzers attract increasing attention of the electrochemical community, and one of their supposed advantages is their larger electrode materials stability than for their proton-exchange membrane analogues. However, stability of the core materials of fuel cells and electrolyzers in alkaline environment is not granted and remains understudied so far. Herein, using in situ Fourier-transform infrared spectroscopy (FTIR), identical-location transmission electron microscopy (IL-TEM), X-ray photoelectron spectroscopy (XPS) and $\mathrm{CO}_{\mathrm{ads}}$ stripping techniques, we provide physical and chemical evidences that Pt-based nanocatalysts catalyze the electrochemical corrosion of the carbon support (Vulcan XC72). This is due to more facile oxidation of oxygen-containing surface groups of the carbon support upon adsorption of
\end{abstract}


hydroxyl groups on the Pt-based surface. The degradation mechanism is, to some extent, similar for other carbon-supported Pt group metal (PGM) electrocatalysts. We propose that the extent of degradation of PGM/C nanoparticles in alkaline electrolytes scales with the electrocatalyst's activity to electrooxidize $\mathrm{CO}$, thereby providing a marker of the materials propensity to degradation in alkaline environment.

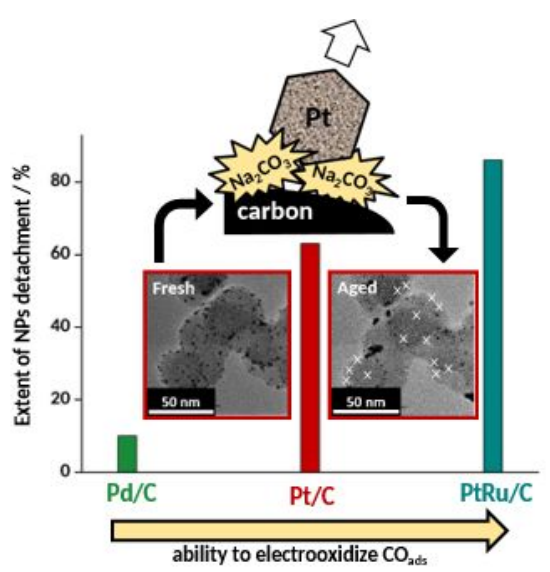

\title{
KEYWORDS
}

\author{
Alkaline Fuel Cells, Degradation Mechanism, PGM-containing Carbon-supported \\ Electrocatalyst, Fourier-transform infrared spectroscopy, Identical-Location Transmission \\ Electron Microscopy
}

\section{INTRODUCTION}

In an economic and environmental context where the usage of fossil energies must slow down, the scientific community is working hard on the development of alternative systems for energy storage and conversion. Electrolyzers and fuel cells are promising technologies of the sort, that 
could enable long-term and large-scale storage of renewable electricity ${ }^{1,2}$. Among the wide range of fuel cells and electrolyzer systems, alkaline fuel cells (AFC) ${ }^{3-6}$ and alkaline water electrolyzers (AWE) ${ }^{7,8}$ have attracted increasing attention over the past few years due to their advantages with respect to acidic technologies: they benefit from faster oxygen reduction reaction (ORR) or oxygen evolution reaction (OER) kinetics, possibilities to use less platinum group metals (PGM) at their electrodes, a wide choice of fuel in addition to hydrogen (alcohol ${ }^{9-11}$, sodium borohydride ${ }^{12}$, hydrazine borane ${ }^{13,14}$ can feed so-called direct liquid fuel AFC) and a wider range of polymer chemistries compared to proton exchange membranes ${ }^{15,16}$.

However, very few studies have focused on the durability of the electrocatalysts used in AFC and AWE systems, the usual belief being that alkaline environment prevents severe degradations of electrode materials (for anion exchange membranes, the community is well aware of the issues at stake $\left.{ }^{17,18}\right)$. However, the durability of electrodes in alkaline environment is not granted, as already put forth in the past, both for PGM ${ }^{19,20}$ and non-PGM ${ }^{21}$ electrodes, at least in liquid hydroxide electrolytes. Based on these early studies, more systematic investigations were carriedout by us ${ }^{22-25}$. The results showed that $\mathrm{Pt} / \mathrm{C}$ electrocatalysts undergo severe degradation upon potential cycling between high ( $1.2 \mathrm{~V} v s$. the reversible hydrogen electrode, RHE) and low $(0.1 \mathrm{~V}$ vs. RHE) potential limits, leading to a $c a .60 \%$ loss of the electrochemical surface area (ECSA) that mostly results from detachment of the metal nanoparticles (NPs) from the carbon substrate. Interestingly, Raman and X-ray photoelectron spectroscopy (XPS) revealed that neither extensive carbon corrosion nor Pt dissolution could rationalize such degradations. According to the Pourbaix diagram ${ }^{26}$, carbon is not stable in strong bases $(\mathrm{pH}=14)$ above $0.06 \mathrm{~V} v s$. RHE and forms dissolved carbonates $\left(\mathrm{CO}_{3}{ }^{2-}\right)$ that spontaneously lead to surface passivation, by formation of solid alkali-metal carbonates (e.g. $\mathrm{Na}_{2} \mathrm{CO}_{3}$ or $\mathrm{K}_{2} \mathrm{CO}_{3}$ in $\mathrm{NaOH}$ or $\mathrm{KOH}$ electrolytes). 
Nevertheless, this protection can be insufficient in strong bases, the pioneering work of Ross et al. ${ }^{27-30}$ having shown that $\mathrm{CO}_{2}$ formation (gasification, observed for $E>1.5 \mathrm{~V}$ and $T>60^{\circ} \mathrm{C}$ ) or dissolution (observed for $E<1.4 \mathrm{~V}$ and $T<50^{\circ} \mathrm{C}$ ) of carbon could proceed, both processes being likely promoted by the presence of $3 \mathrm{~d}$ transition metals/oxides immobilized at the carbon. A deeper understanding was provided by a first run of in situ FTIR characterizations of the aging of $\mathrm{Pt} / \mathrm{C}$ in $0.1 \mathrm{M} \mathrm{NaOH}$ during potential cycling between $0.1<E<1.2 \mathrm{~V} v s$. RHE: the formation of carbonates species was asserted ${ }^{25}$. In the same paper, the ECSA losses were also linked to the nature of the alkali metal cations (M) of the $\mathrm{MOH}$ electrolyte: $\mathrm{Li}^{+}, \mathrm{Na}^{+}, \mathrm{K}^{+}$, and $\mathrm{Cs}^{+}$based electrolytes, for which the alkali metal carbonates are more soluble in the sequence $\mathrm{Li}^{+}, \mathrm{Na}^{+}, \mathrm{K}^{+}$ to $\mathrm{Cs}^{+}$, lead to decreasing ECSA losses. All these studies suggest that formation of solid carbonates in $\mathrm{MOH}$ electrolytes is favored at the $\mathrm{Pt} \mid$ carbon support interface, but fundamental insights about the degradation mechanism of PGM-electrocatalysts are still lacking.

Herein, FTIR experiments were conducted in a stepwise manner to detect precisely at which electrode potential carbonates do form. In addition, both the influence of Pt weight fraction (wt. $\%$ ) and the nature of the metal NPs ( $\mathrm{Pd}$ and PtRu in addition to Pt) were investigated, in the hope to (i) assert the degradation mechanism of $\mathrm{Pt} / \mathrm{C}$ in base, but also to (ii) possibly generalize this proposed mechanism to the most studied carbon-supported PGM electrocatalysts in alkaline fuel cells and water electrolyzers.

\section{EXPERIMENTAL SECTION}

\subsection{Electrocatalysts}

The carbon-supported electrocatalysts were purchased from E-TEK or Premetek and used as received. They are all supported on Vulcan XC72 carbon black and are referred to as 10, 40 or 80 wt. \% Pt/C, 10 or 40 wt. \% PtRu/C and 10 or 40 wt. \% Pd/C depending on the metal wt. \%. 


\subsection{Morphological characterizations}

TEM and IL-TEM observations were performed using a Jeol 2010 TEM apparatus equipped with a $\mathrm{LaB}_{6}$ filament operating at $200 \mathrm{kV}$. In the case of the bimetallic PtRu/C electrocatalyst, scanning transmission electron microscopy (STEM) images and associated X-ray energy dispersive spectroscopy (X-EDS) elemental maps were acquired using a JEOL 2100F microscope operated at $200 \mathrm{kV}$ equipped with a SDD Centurio retractable detector. The X-EDS spectra were recorded on selected zones of the TEM grid aged in Identical Location mode. The $\mathrm{Pt} M$ and $\mathrm{Ru} L$ lines were used to determine the elemental maps.

\subsection{X-ray photoelectron spectroscopy (XPS)}

XPS patterns were obtained using a Thermo Scientific K-alpha spectrometer with a monochromatized Al X-ray source $(\mathrm{h} v=1486.6 \mathrm{eV}$; spot size $=400 \mu \mathrm{m})$. Pass energies of 30 and $100 \mathrm{eV}$ were used to record the core level and the survey spectra, respectively. All spectra were acquired using an electron flood gun to compensate possible positive charge accumulation during measurements. The obtained spectra were deconvoluted and fitted using Thermo Scientific ${ }^{\mathrm{TM}}$ Advantage Software. The evolution of the oxygen content during the AST was monitored by dividing the peak areas of the $\mathrm{O} 1 \mathrm{~s}$ and the $\mathrm{C} 1 \mathrm{~s}$ signal (without the contribution of Nafion ${ }^{\circledR}$-related envelopes), after proper background subtraction, by their respective atomic sensitivity factors: ratio $\left(\frac{O 1 s}{C 1 s}\right)=\frac{I_{O 1 s}}{0.63} * \frac{0.205}{I_{C 1 s}}$

\subsection{Electrochemical material}

All the electrochemical measurements were performed using a Bio-Logic $₫$ potentiostat (SP300). The glassware and plastic accessories used for the experiments were soaked in Caro's acid (1-1 vol. $\% \mathrm{H}_{2} \mathrm{O}_{2}(30 \mathrm{w} / \mathrm{v} \%)-\mathrm{H}_{2} \mathrm{SO}_{4}(>95 \mathrm{wt}$. \%)) overnight to prevent organic and metallic 
pollution, and thoroughly rinsed with ultrapure water $(18.2 \mathrm{M} \Omega \mathrm{cm},<3 \mathrm{ppm}$ Total Organic Carbon, Millipore Elix + Gradient, Millipore) prior being used.

The in situ FTIR spectroscopy measurements were conducted using a homemade three-electrode electrochemical cell. The counter electrode was a platinum mesh and the reference electrode was a freshly-prepared RHE. The electrolyte $(0.1 \mathrm{M} \mathrm{NaOH})$ was daily prepared using $\mathrm{NaOH}, \mathrm{H}_{2} \mathrm{O}$ crystals (Suprapur, Merck) dissolved in ultrapure water. The working electrodes were prepared using suspensions made of each of the electrocatalyst mentioned above, ultrapure water, 5 wt. \% Nafion ${ }^{\circledR}$ solution and isopropyl alcohol (IPA) in quantities given in Table 1. After 20 min of sonication, the working electrodes were prepared by depositing $8 \mu \mathrm{L}$ of the desired ink on a 1 cm-diameter gold electrode and then dried in an oven at $T=110^{\circ} \mathrm{C}$. The same quantity of carbon was deposited on the gold electrode whatever the initial metal wt. \%, so as to compare thin-film electrodes of the same thickness.

Table 1. Ink preparation for the FTIR experiments.

\begin{tabular}{|c|c|c|c|c|}
\hline Commercial catalyst & $\begin{array}{c}\text { Electrocatalyst } \\
\text { (mg) }\end{array}$ & $\begin{array}{l}\mathrm{H}_{2} \mathrm{O} \\
(\mu \mathrm{L})\end{array}$ & $\begin{array}{c}\text { Nafion } \$ 5 \text { wt. \% } \\
(\mu \mathrm{L})\end{array}$ & $\begin{array}{l}\text { IPA } \\
(\mu \mathrm{L})\end{array}$ \\
\hline 10 wt. $\%$ Pt/C E-TEK & 10 & 5770 & 18.3 & 2000 \\
\hline 40 wt. $\%$ Pt/C E-TEK & 10 & 3590 & 41.2 & 1600 \\
\hline 80 wt. $\%$ Pt/C E-TEK & 10 & 1405 & 1.37 & 330 \\
\hline 40 wt. $\%$ PtRu/C E-TEK & 10 & 3590 & 41.2 & 1600 \\
\hline 40 wt. $\% \mathrm{Pd} / \mathrm{C}$ Premetek & 10 & 3590 & 41.2 & 1600 \\
\hline
\end{tabular}


The $\mathrm{CO}_{\mathrm{ads}}$ stripping experiments were conducted in a four-electrode electrochemical cell. The counter electrode was a glassy carbon plate, the reference electrode was a freshly prepared RHE and a gold wire was connected to the reference electrode via a capacitor bridge in order to avoid electrical noise ${ }^{31}$. The working electrodes were obtained by depositing $10 \mu \mathrm{L}$ of a suspension (containing $10 \mathrm{mg}$ of electrocatalyst, $1755 \mu \mathrm{L}$ of ultrapure water, $61 \mu \mathrm{L}$ of 5 wt. $\%$ Nafion ${ }^{\circledR}$ solution and $730 \mu \mathrm{L}$ of IPA) on a $5 \mathrm{~mm}$-diameter glassy-carbon electrode, yielding a loading of $20 \mu \mathrm{g}_{\text {metal }} \mathrm{cm}_{\text {geom }^{-2}}$ to ease comparison between the various samples. This drop was then dried with a heat gun while the electrode was rotated, as recommended by Garsany et al. ${ }^{32}$. The electrolyte was $0.1 \mathrm{M} \mathrm{NaOH}$ and was daily prepared as described above. A similar electrochemical setup was used to perform the accelerated stress tests (AST), however, the working electrode was different: the electrocatalyst inks was deposited onto a gold TEM grid held in the electrolyte by two carbon plates to ensure electronic conduction.

\subsection{Measurement protocols}

FTIR measurements were performed using a Bruker Vertex $70 \mathrm{~V}$ spectrometer. $\mathrm{A} \mathrm{CaF}_{2}$ prism beveled at $60^{\circ}$ constituted the bottom of the electrochemical cell. The spectra were collected in external reflection using $p$-polarized light and a liquid- $\mathrm{N}_{2}$-cooled MCT (Mercury-CadmiumTelluride) detector. The single-beam spectra were obtained by co-adding 512 interferograms acquired at $4 \mathrm{~cm}^{-1}$ spectral resolution with an interferometer frequency of $40 \mathrm{kHz}$ and then Fourier transformed.

For the in situ FTIR measurements, the working electrode was first introduced in the cell, and after $15 \mathrm{~min}$ of Ar bubbling, 5 cyclic voltammograms were recorded from $E=0.1$ to $1.23 \mathrm{~V} v s$. RHE at $v=50 \mathrm{mV} \mathrm{s}^{-1}$ in a hanging-meniscus configuration. Then, the working electrode was 
pressed against the $\mathrm{CaF}_{2}$ prism (thin layer configuration), its potential being maintained at $E=$ $0.1 \mathrm{~V}$ vs. RHE. When an electrode position with an optimum reflectivity was obtained, 5 spectra were registered. Next, a succession of $100 \mathrm{mV}$ steps increased the working electrode potential up to $E=1.2 \mathrm{~V} v s$. RHE, an intermediate step to the low (control) potential $E=0.1 \mathrm{~V} v s$. RHE being applied between each potential step. 512 interferograms were collected at each step and data were plotted using relative reflectivity $R_{\mathrm{E}} / R_{\text {ref, where }} R_{\mathrm{E}}$ and $R_{\text {ref }}$ are the reflectivity obtained at the desired potential $(E=0.2,0.3, \ldots, 1.2 \mathrm{~V} v s . \mathrm{RHE})$ and the reference potential (mainly $0.1 \mathrm{~V} v s$. RHE), respectively. With this methodology, positive-going bands correspond to species consumption and negative-going bands correspond to species production.

For the in situ FTIR $\mathrm{CO}_{\text {ads }}$ stripping experiments, the electrolyte was purged with $\mathrm{CO}$ for 6 min, and then with Ar for 39 min to ensure that no dissolved $\mathrm{CO}$ remained in the bulk of the electrolyte. During this process, the working electrode was permanently pressed against the $\mathrm{CaF}_{2}$ prism while keeping its potential at $E=0.1 \mathrm{~V} v s$. RHE. Then, the same succession of potential steps as described above was applied.

The $\mathrm{CO}_{\mathrm{ads}}$ stripping experiments conducted in the conventional cell were performed by bubbling $\mathrm{CO}$ for $6 \mathrm{~min}$ and then Ar for $39 \mathrm{~min}$. Next, 3 cyclic voltammetry (CV) cycles were recorded between $0.1<E<1.33 \mathrm{~V} v s$. RHE at a potential sweep rate $v=20 \mathrm{mV} \mathrm{s}^{-1}$.

The AST performed in this study consisted of 150 potential cycles between $E=0.1$ and $1.23 \mathrm{~V}$ $v s$. RHE using a linear sweep ramp and $v=100 \mathrm{mV} \mathrm{s}^{-1}$. The electrolyte was $0.1 \mathrm{M} \mathrm{NaOH}$ and the temperature $T=25^{\circ} \mathrm{C}$.

\section{RESULTS AND DISCUSSION}




\subsection{In situ FTIR spectroscopy on Pt/C}

The FTIR spectra obtained under stepwise oxidation conditions on 10,40 and $80 \mathrm{wt} . \% \mathrm{Pt} / \mathrm{C}$ in $0.1 \mathrm{M} \mathrm{NaOH}$ are shown in Figure 1. Four negative-going bands, located at 1380, 1610, 1710 and $1960 \mathrm{~cm}^{-1}$, and one positive-going band at $1670 \mathrm{~cm}^{-1}$, are noticed on $10 \mathrm{wt} . \% \mathrm{Pt} / \mathrm{C}$. Similarly, the FTIR spectra measured on the 40 and $80 \mathrm{wt} . \% \mathrm{Pt} / \mathrm{C}$ are composed of five negative-going bands at $1310,1390,1580,1730-1760$ and $2010 \mathrm{~cm}^{-1}$ and one positive-going band at $1670 \mathrm{~cm}^{-1}$. 

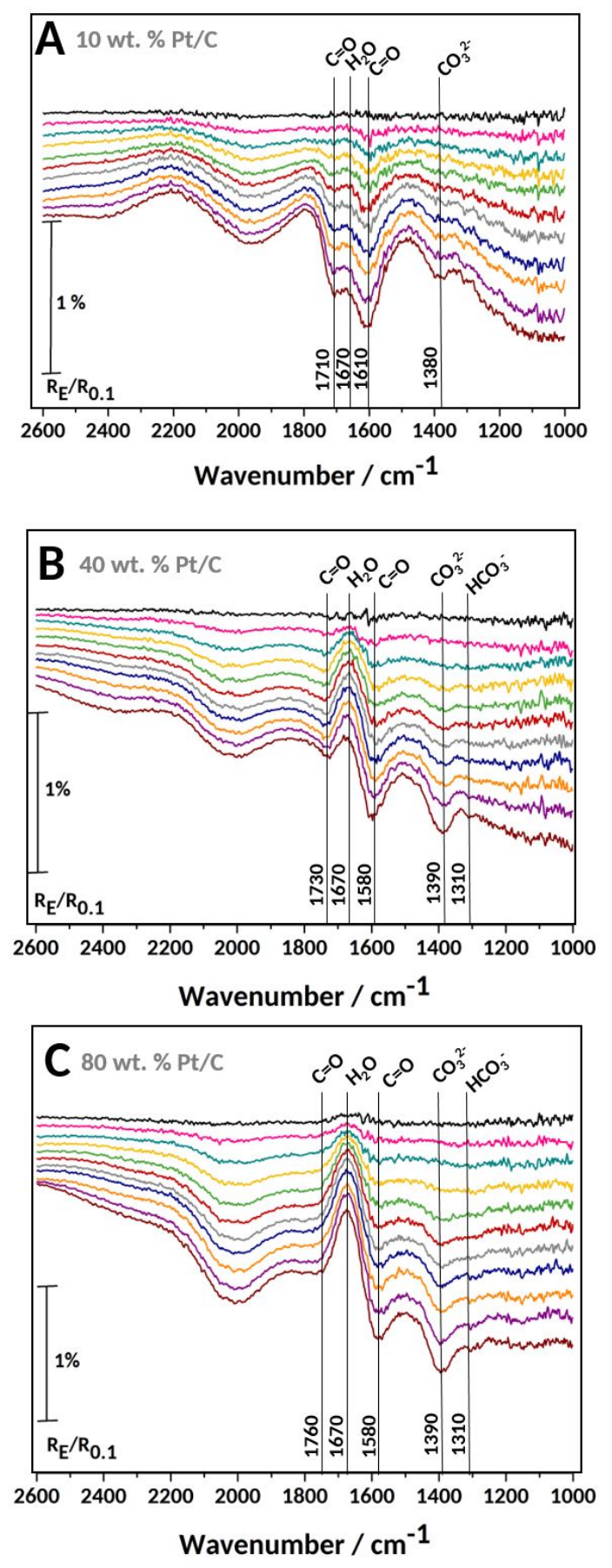

$\mathbf{0} .2 \mathrm{~V}$ vs. RHE $0.5 \mathrm{~V}$ vs. RHE $0.8 \mathrm{~V}$ vs. RHE $1.1 \mathrm{~V}$ vs. RHE $0.3 \mathrm{~V}$ vs. RHE $0.6 \mathrm{~V}$ vs. RHE $0.9 \mathrm{~V}$ vs. RHE $1.2 \mathrm{~V}$ vs. RHE $0.4 \mathrm{~V}$ vs. RHE $0.7 \mathrm{~V}$ vs. RHE $1.0 \mathrm{~V}$ vs. RHE 
In agreement with past studies ${ }^{33-40}$, the bands at $1380-1390 \mathrm{~cm}^{-1}$ and $1310 \mathrm{~cm}^{-1}$ were assigned to carbonate ions $\left(\mathrm{CO}_{3}{ }^{2-}\right)$ and bicarbonate ions $\left(\mathrm{HCO}_{3}{ }^{-}\right)$, respectively. For all the electrocatalysts, the intensity of the carbonate features increased along with an increase of the electrode potential: this strongly supports our former assumption ${ }^{25}$ that the degradation of Pt/C NPs involves the production of carbonate ions. The impact of the $\mathrm{Pt}$ wt. \% is also noticeable: the carbonate band $\left(1380-1390 \mathrm{~cm}^{-1}\right)$ appears at $E=0.8 \mathrm{~V} v s$. RHE for $10 \mathrm{wt} . \% \mathrm{Pt} / \mathrm{C}$ and at $E=0.5 \mathrm{~V} v s$. RHE for 40 and $80 \mathrm{wt} . \% \mathrm{Pt} / \mathrm{C}$. The area of this band was integrated at each electrode potential, as shown in Figure S1, and the results are displayed in Figure 2.They reveal that higher Pt ECSA enables 
formation of carbonate species at lower potential (therefore quantitatively more carbonate formation at a given potential).

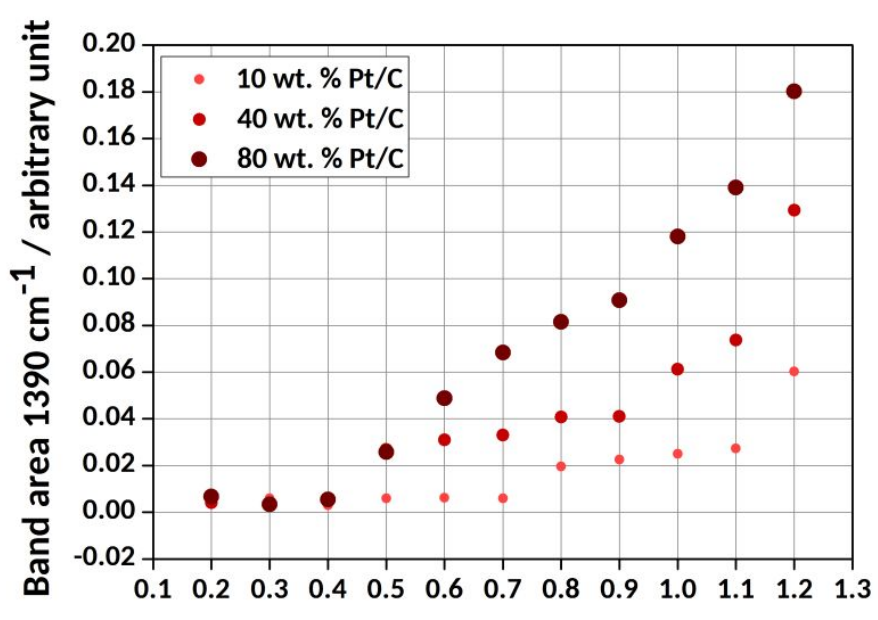

E / V vs. RHE

Figure 2. Area developed by the $1390 \mathrm{~cm}^{-1}$ band at different electrode potential on 10,40 and $80 \mathrm{wt}$ \% $\mathrm{Pt} / \mathrm{C}$.

The bands located at $1580-1610 \mathrm{~cm}^{-1}$ and $1710-1730-1760 \mathrm{~cm}^{-1}$ were assigned to oxygencontaining surface groups on carbon, namely quinone or carboxylate and carbonyl/carboxylic acid group, respectively ${ }^{40-46}$. As the standard potential of carbon oxidation reaction is $E^{0}=0.06$ V vs. RHE according to the Pourbaix diagram in alkaline media ${ }^{26}$, the production of $\mathrm{CO}, \mathrm{CO}_{2}$, surface oxides or organic-carbon products are expected in the potential range investigated in this study $\left(0.1<E<1.2 \mathrm{~V} v s\right.$. RHE). More practically, the band at $1710-1730-1760 \mathrm{~cm}^{-1}$ (carbonyl/carboxylic acid groups) appears at $E=0.5,0.3$ and $0.3 \mathrm{~V} v s$. RHE for Pt/C 10, 40 and 80 wt. $\%$, respectively, while the band at $1580-1610 \mathrm{~cm}^{-1}$ (quinone and/or carboxylate) appears at $E=0.3,0.3$ and $0.4 \mathrm{~V} v s$. RHE for Pt/C 10, 40 and 80 wt. \%, respectively. This means that, for all $\mathrm{Pt} / \mathrm{C}$ electrocatalysts, oxygen-containing surface groups form on carbon at low potential $(0.2<$ $E<0.6 \mathrm{~V} v s$. RHE, see Equation 1). Then, two scenarios can be considered. In scenario \# 1, 
In the two suggested degradation mechanisms, water and carbonate species are supposed to be produced simultaneously. Thus, a negative-going band is expected for water bending at $1645 \mathrm{~cm}^{-}$ 140 . This band is located at $1670 \mathrm{~cm}^{-1}$ in our study and points positive for the three electrocatalysts, which suggest consumption (or loss) of water. One possible explanation for the apparent consumption of water would imply a change of carbon surface properties from hydrophilic to hydrophobic. Indeed, it is well-known that oxygen-containing surface groups are present on the native carbon surface (Equation 1): the surface of the carbon support is thus necessarily hydrophilic in the fresh state. It is therefore expected that the consumption of these 
oxygenated functions (Equation 2 and 5) leads to a change in its wetting properties. Because the thin layer formed between the electrode surface and the prism has a fixed volume and is diffusionally-isolated, the repulsion of water from the carbon support $\left(\mathrm{C}_{\mathrm{n}}\right)$ occurring upon electrode potential increase would result in a positive-going water bending band at $1645 \mathrm{~cm}^{-1}$ in FTIR spectra. The higher this intensity, the more hydrophobic the carbon surface, as a result of the more pronounced corrosion of the oxygen-containing surface groups into $\mathrm{CO}_{2}$ and production of metal carbonates. The corrosion of oxygen-containing surface groups also takes place in acidic media, as described recently in Refs ${ }^{47,48}$.

According to the proposed mechanisms, two other species should have been detected: $\mathrm{CO}_{2}$ and CO (only for scenario \# 1). The main infrared spectroscopy features of these species are bands with strong intensities located at $2345 \mathrm{~cm}^{-1}$ and $c a .2045 \mathrm{~cm}^{-1}$ respectively $33,37,49,50$, but none of them was detected in our study. This apparent discrepancy can be explained, though. Firstly, $\mathrm{CO}_{2}$ is an intermediate species in the proposed corrosion mechanism but this product is rapidly converted to $\mathrm{CO}_{3}{ }^{2-}$ in alkaline media. FTIR spectroscopy being a quasi-stationary measurement, the detection of transient species is very tricky, explaining the absence of $\mathrm{CO}_{2}$ related bands in our experiments. Secondly, regarding the formation of $\mathrm{CO}$ in scenario \# 1, it is postulated that too little CO is produced (well below a complete monolayer on the Pt NPs), because COcontaining groups mostly originate from a limited reservoir (the $\mathrm{Pt} \mid \mathrm{C}$ interface) and are oxidized at potential above $0.4 \mathrm{~V}$ vs. RHE (Figure 1 and Figure 9). Hence in the conditions of our study, $\mathrm{CO}_{\text {ads }}$ species will hardly accumulate on the Pt surface.

Finally, according to FTIR measurements performed on polycrystalline gold (the electrode used for FTIR measurements) in the same conditions (Figure S2), the very broad negative-going band located around $2000 \mathrm{~cm}^{-1}$ on all the spectra might be assigned to a change of gold reflectivity 
during the experiment (e.g. because gold progressively gets covered by $\mathrm{OH}_{\mathrm{ads}}$ and/or surface oxides ${ }^{51}$ ). This broad band is noticeable on all the spectra presented in this study and the assignment is identical for all of them.

3.2 Additional investigations about the degradation mechanism

\subsubsection{In situ FTIR spectroscopy and XPS measurement on Vulcan XC72}

To confirm that the degradation of $\mathrm{Pt} / \mathrm{C}$ electrocatalysts in alkaline media comes from a Ptassisted local corrosion of the carbon support, similar FTIR experiments were performed on bare Vulcan XC72, and the results are presented in Figure 3. In addition, FTIR measurements on Vulcan XC72 using a more extensive AST (150 potential cycles between $E=0.1$ and $1.23 \mathrm{~V} v s$. RHE at $v=100 \mathrm{mV} \mathrm{s}^{-1}$ ) were performed (Figure S3) and XPS measurement on bare Vulcan $\mathrm{XC72}$ and 40 wt. \% Pt/C were carried-out before and after the same AST procedure (Figure S4). 


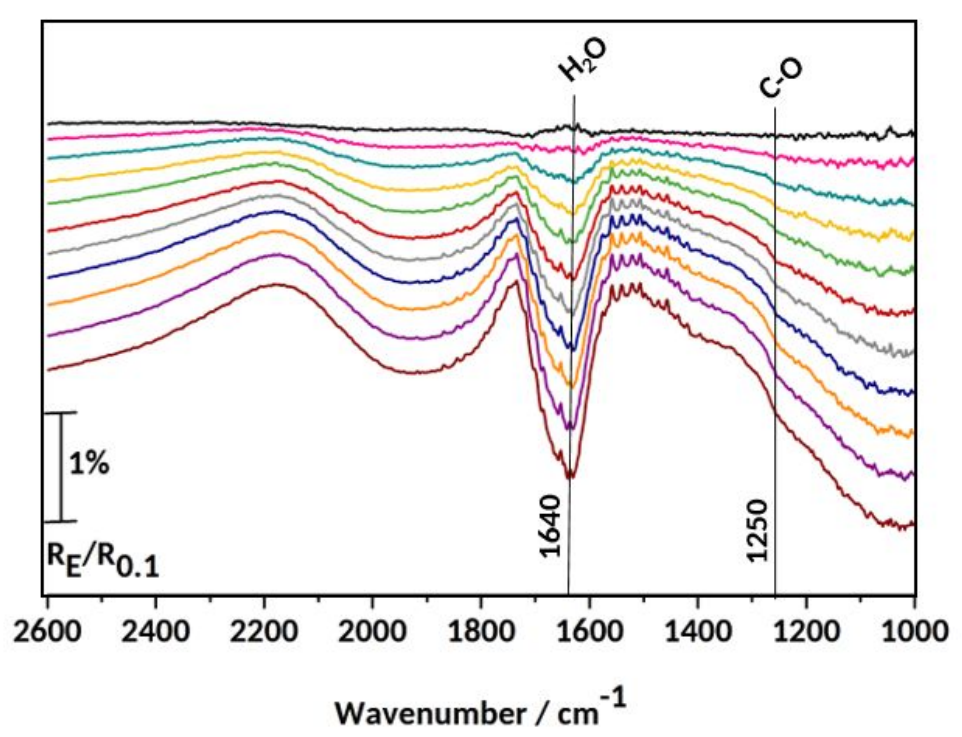

\section{$0.2 \mathrm{~V}$ vs. RHE $0.5 \mathrm{~V}$ vs. RHE $0.8 \mathrm{~V}$ vs. RHE $1.1 \mathrm{~V}$ vs. RHE $0.3 \mathrm{~V}$ vs. RHE $0.6 \mathrm{~V}$ vs. RHE $0.9 \mathrm{~V}$ vs. RHE $1.2 \mathrm{~V}$ vs. RHE $0.4 \mathrm{~V}$ vs. RHE $0.7 \mathrm{~V}$ vs. RHE $1.0 \mathrm{~V}$ vs. RHE}

Figure 3. FTIR spectra obtained under stepwise oxidation conditions from $E=0.1$ to $1.2 \mathrm{~V} v s$. RHE in $0.1 \mathrm{M} \mathrm{NaOH}$ on Vulcan XC72 (the relative reflectivity is calculated using the spectra obtained at $E=0.1 \mathrm{~V} v s$. RHE as the reference reflectivity).

During the stepwise oxidation, a very weak shoulder located at $1250 \mathrm{~cm}^{-1}$ develops on the FTIR spectra, which is assigned to $\mathrm{C}-\mathrm{O}$ stretching ${ }^{41}$; a broad negative-going band located at $1640 \mathrm{~cm}^{-1}$ was assigned to $\mathrm{H}-\mathrm{O}-\mathrm{H}$ bending, signing water production. However, no band relative to carbonate species was detected, putting into evidence that no or limited quantities of (bi)carbonates are produced in the absence of Pt: this results supports our previous hypothesis that (bi)carbonates are formed following $\mathrm{CO}_{2}$ production on Pt sites. Nevertheless, no band (other than the one located at $1250 \mathrm{~cm}^{-1}$ ) related to oxygen-containing surface groups was detected in the absence of Pt NPs. It is possible that the bands linked to the oxygen-containing surface groups could be drowned in the broadband located at $1640 \mathrm{~cm}^{-1}$, that may be dominated by the change of reflectivity of the Au substrate (see Figure S2). 
These oxygen-containing surface groups are nevertheless observed on the FTIR spectra of the Vulcan XC72 carbon when it is submitted to a more extensive AST (150 potential cycles between $E=0.1$ and $1.23 \mathrm{~V} v s$ RHE at $\left.v=100 \mathrm{mV} \mathrm{s}^{-1}\right)$ : bands located at $1590 \mathrm{~cm}^{-1}$ and $1740 \mathrm{~cm}^{-1}$ are clear on Figure S3, and they grow with the number of CV cycles performed. XPS measurements have also been performed pre and post $150 \mathrm{CV}$ cycles of this AST for bare Vulcan XC72 and 40 wt.\% Pt/C (Figure S4). The evolution of the oxygen content during AST was estimated using the $\mathrm{O} 1 \mathrm{~s} / \mathrm{C} 1 \mathrm{~s}$ ratio (without the contribution of $\mathrm{Nafion}^{\circledR}$-related envelopes and corrected from the atomic sensitivity factors). The $\mathrm{O} 1 \mathrm{~s} / \mathrm{C} 1 \mathrm{~s}$ ratio increases from 0.10 to 0.18 upon the AST for Vulcan XC72, but remains stable for 40 wt. $\% \mathrm{Pt} / \mathrm{C}(\mathrm{O} 1 \mathrm{~s} / \mathrm{C} 1 \mathrm{~s}=0.19$ and 0.18 pre and post AST, respectively). This suggests that oxygen-containing surface groups do form and accumulate (their signature increases) on the carbon surface when Vulcan XC72 carbon is free of Pt NPs, whereas their proportion remains stable when Pt NPs are present, because the Pt NPs transform them into $\mathrm{CO}_{2}$ and then carbonates upon their formation.

Another possible mechanism could be similar to that described by Yi and coworkers ${ }^{52}$, who recently studied the electrochemical corrosion of glassy carbon (GC) in alkaline media. FTIR spectroscopy measurement on GC oxidized in alkaline media ( $U=1.8 \mathrm{~V} v s$. RHE during 24 hours in $0.1 \mathrm{M} \mathrm{KOH}$ ) revealed no change compared to the pristine GC. Similarly, the Raman and XPS spectra and the cyclic voltammograms measured on the pristine and aged GC were nearly identical. To rationalize their findings, the authors postulated that the oxidation of GC in alkaline media occurs via a reaction of $\mathrm{OH}^{\circ}$ radicals (produced by discharge of $\mathrm{OH}^{-}$ions) with alkyl site chains, leading to transient oxidation of the edges of carbon layers until they become hydrophilic and dissolve, thus exposing a "fresh" GC surface. 


\subsection{2 $\mathrm{CO}_{\mathrm{ads}}$-electrooxidation on polycrystalline $\mathrm{Pt}$}

To support our hypotheses, the electrooxidation of a $\mathrm{CO}_{\mathrm{ads}}$ monolayer in alkaline media was investigated on polycrystalline Pt. The results are displayed in Figure 4, and data are plotted using either the spectrum measured at $E=0.1 \mathrm{~V} v s$. RHE (Figure 4-A) or that measured at $E=$ 1.1 V vs. RHE (Figure 4-B) as a reference spectrum. 
Figure 4. FTIR spectra obtained for $\mathrm{CO}_{\text {ads }}$ electrooxidation on polycrystalline $\mathrm{Pt}$ under stepwise oxidation conditions in $0.1 \mathrm{M} \mathrm{NaOH}$. The electrode potential was stepped from $E=0.1$ to $1.2 \mathrm{~V}$ vs. RHE; the relative reflectivity was calculated using the FTIR spectra obtained at A) $E=0.1 \mathrm{~V}$ vs. RHE and B) $E=1.1 \mathrm{~V} v s$. RHE as the reference reflectivity.

Figure 4-A shows two negative-going bands located at 1390 and $1630 \mathrm{~cm}^{-1}$, corresponding to carbonates and water production, respectively. Figure 4-B shows that $\mathrm{CO}_{\mathrm{ads}}$ consumption is concomitant with $\mathrm{CO}_{3}{ }^{2-}$ production: the $\mathrm{CO}_{\text {ads }}$ feature, located at $2014 \mathrm{~cm}^{-1}$ for $E=0.1 \mathrm{~V} v s$. RHE 
starts to disappear for $0.3 \mathrm{~V} v s$. RHE and above, in parallel to the appearance of a positive band of water, sign of its generation in the process (as expected).

It is interesting to remark that carbonates are produced at lower potential on polycrystalline $\mathrm{Pt}$ relative to $\mathrm{Pt} / \mathrm{C}$ electrocatalysts: the band at $1390 \mathrm{~cm}^{-1}$ is detected at $E=0.3 \mathrm{~V} v s$. RHE on polycrystalline Pt, and at $E=0.8$ or $0.5 \mathrm{~V} v s$. RHE for Pt/C at low or high wt. \%, respectively. Moreover, the carbonates feature grows up to $E=0.5 \mathrm{~V} v s$. RHE and starts to decrease above $E=$ $0.6 \mathrm{~V}$ vs. RHE on polycrystalline Pt (because the CO source is limited), whereas the band keeps growing on the $\mathrm{Pt} / \mathrm{C}$ electrocatalysts (because the $\mathrm{CO}$ source is huge). Since all conditions were kept identical, this result nicely confirms that an equilibrium between the rate of carbonate formation and dissolution takes place in the thin layer formed between the electrode surface and the $\mathrm{CaF}_{2}$ prism. In the $\mathrm{CO}_{\text {ads }}$ stripping experiment on polycrystalline $\mathrm{Pt}$, the limited quantity of $\mathrm{CO}$ species facilitates the dissolution of carbonate species on the long term. In contrast, the corrosion of the carbon support promotes the renewal of a native carbon surface on Vulcan $\mathrm{XC72}$, which is then oxidized into $\mathrm{CO}_{2}$ and ultimately carbonate species. The process is operating until the Pt nanoparticle detaches from the support.

3.3 Towards a generalization of the mechanism: the case of PtRu/C and Pd/C To generalize our findings, FTIR spectra were recorded on 40 wt. \% PtRu/C and 40 wt. \% Pd/C in the same experimental conditions (Figure 5). The high metal wt. \% allowed highlighting whether these PGM catalyze the electrochemical corrosion of the carbon support. This is definitely the case for 40 wt. \% PtRu/C. Indeed, four negative-going bands are observed on this catalyst (Figure 5-A), in particular the bands assigned to the presence of carbonate and bicarbonate ions. Similarly, Pd nanoparticles corrode the carbon support although to a minor extent: the band assigned to carbonates is indeed noticeable (Figure 5-B) but the intensity is very 
weak. In addition, both FTIR spectra show the positive-going band assigned to water and located at $1670 \mathrm{~cm}^{-1}$ : the intensity of this band increases with the production of carbonates as observed previously with the three $\mathrm{Pt} / \mathrm{C}$ electrocatalysts. 

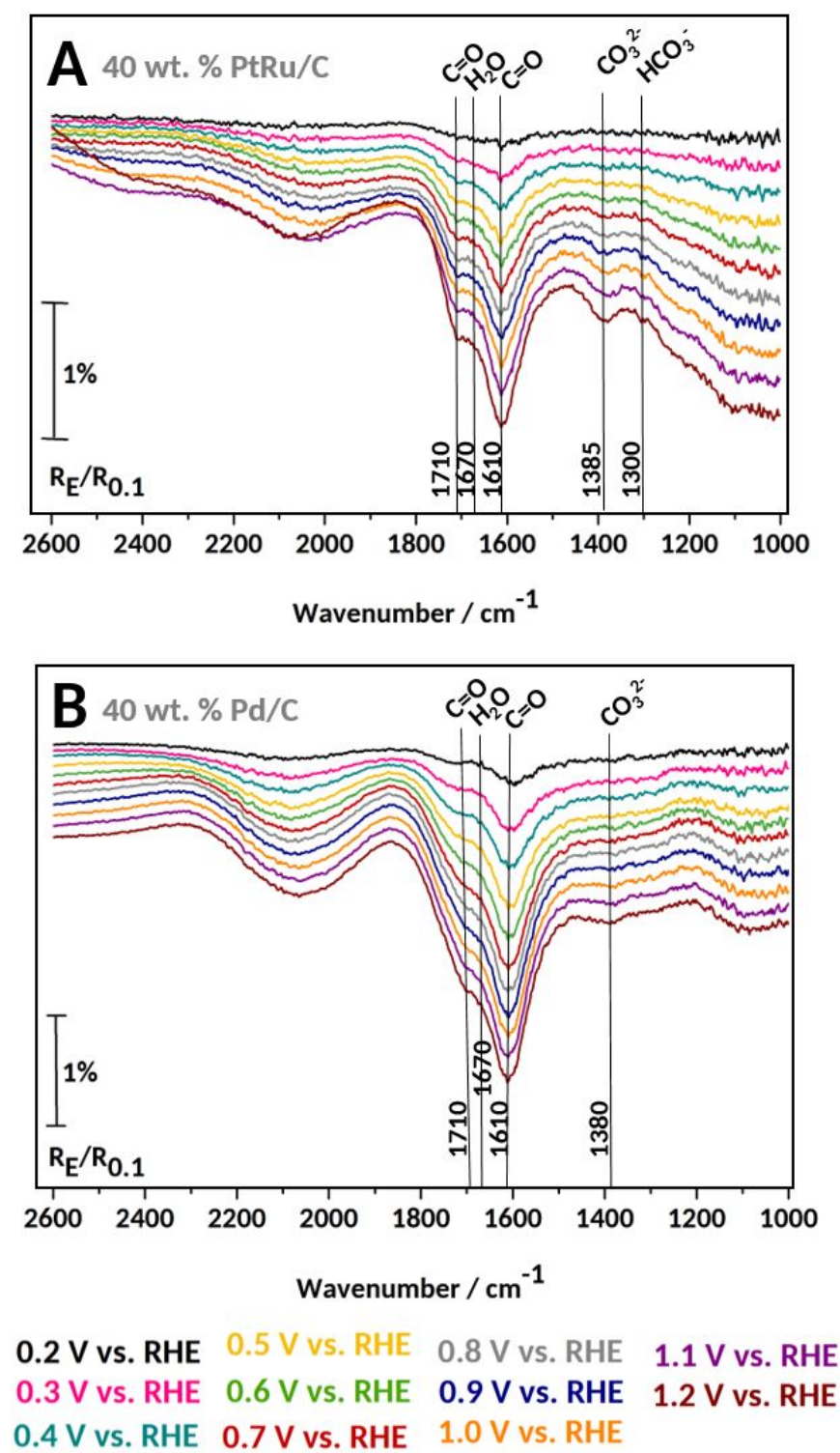

Figure 5. FTIR spectra obtained under stepwise oxidation conditions from $E=0.1$ to $1.2 \mathrm{~V} v s$. RHE in $0.1 \mathrm{M} \mathrm{NaOH}$ on A) $40 \mathrm{wt}$ \% PtRu/C and B) $40 \mathrm{wt} . \% \mathrm{Pd} / \mathrm{C}$; (the relative reflectivity is calculated using the spectra obtained at $E=0.1 \mathrm{~V} v s$. RHE as the reference reflectivity).

The results were quantitatively confirmed by subjecting the three different materials to an accelerated stress test composed of $150 \mathrm{CV}$ cycles between $E=0.1$ and $1.2 \mathrm{~V} v s$. RHE with a sweep rate of $100 \mathrm{mV} \mathrm{s}^{-1}$ in $0.1 \mathrm{M} \mathrm{NaOH}$ at $T=25^{\circ} \mathrm{C}$. Meanwhile, IL-TEM images were 
recorded on the fresh and aged catalysts in the exact same location (Figure 6). Note however that, to facilitate the visualization of the degradation and rebuild the particle size distributions, $10 \mathrm{wt}$. $\%$ catalysts were used. Figure 6-B-C reveals that the majority of the PtRu NPs are detached from the carbon support after the AST (highlighted with the white crosses - these do not pretend to be comprehensive) and that the remaining ones are agglomerated. More precisely, the extent of the NPs detachment reached $86 \%$. Furthermore, a metal deposit could be observed on the membrane of the TEM grid upon ageing (Figure 7 and Figure 8): X-EDS analyses revealed that this deposit is essentially composed of Ru. This finding is in line with the thermodynamic instability of Ru in alkaline environment ${ }^{26}$ and illustrates the fact that Ru likely does not play any role in terms of COR catalysis. The more robust catalyst was clearly Pd/C for which only $10 \%$ of the metal NPs were lost after the AST whereas $63 \%$ are lost in the case of Pt/C. The evolution of the particle size distribution is overall similar for the three catalysts: the proportion of isolated big NPs lowers, while the proportion of isolated small NPs increases, suggesting that small particles are more stable than the big ones in these conditions. In the case of PtRu/C, this result could also result from the preferential dissolution of Ru during the AST. 


\section{extent of NPs detachment}

ability to form $\mathrm{CO}_{2}$
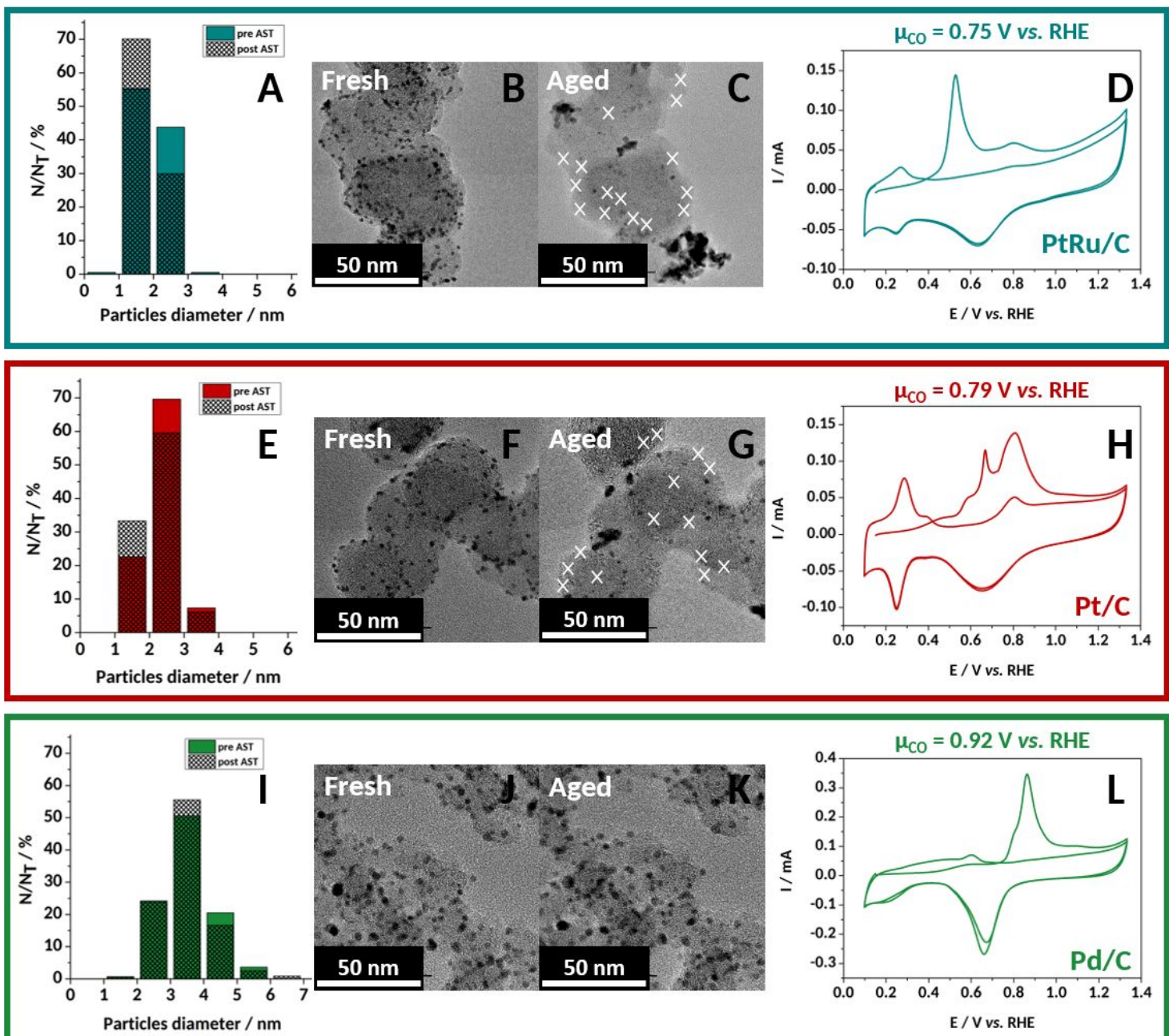

Figure 6. (A, E, I) Particle size distribution for $10 \mathrm{wt} . \% \mathrm{PtRu} / \mathrm{C}$ (blue), $10 \mathrm{wt}$ \% Pt/C (red) and 10 wt. $\% \mathrm{Pd} / \mathrm{C}$ (green) electrocatalysts, $N_{\mathrm{T}}$ is the total number of counted particles ( $\left.c a .200\right)$. ILTEM micrographs (B, F, J) pre-AST and (C, G, K) post-AST on 10 wt. \% PtRu/C (blue), 10 wt. $\% \mathrm{Pt} / \mathrm{C}$ (red) and $10 \mathrm{wt} \% \mathrm{Pd} / \mathrm{C}$ (green). (D, $\mathrm{H}, \mathrm{L}$ ) $\mathrm{CO}_{\text {ads }}$ stripping voltammograms recorded at $v$ $=20 \mathrm{mV} \mathrm{s}^{-1}$ in $0.1 \mathrm{M} \mathrm{NaOH}$ on 10 wt. \% PtRu/C (blue), 10 wt. \% Pt/C (red) and $10 \mathrm{wt} . \% \mathrm{Pd} / \mathrm{C}$ (green). 


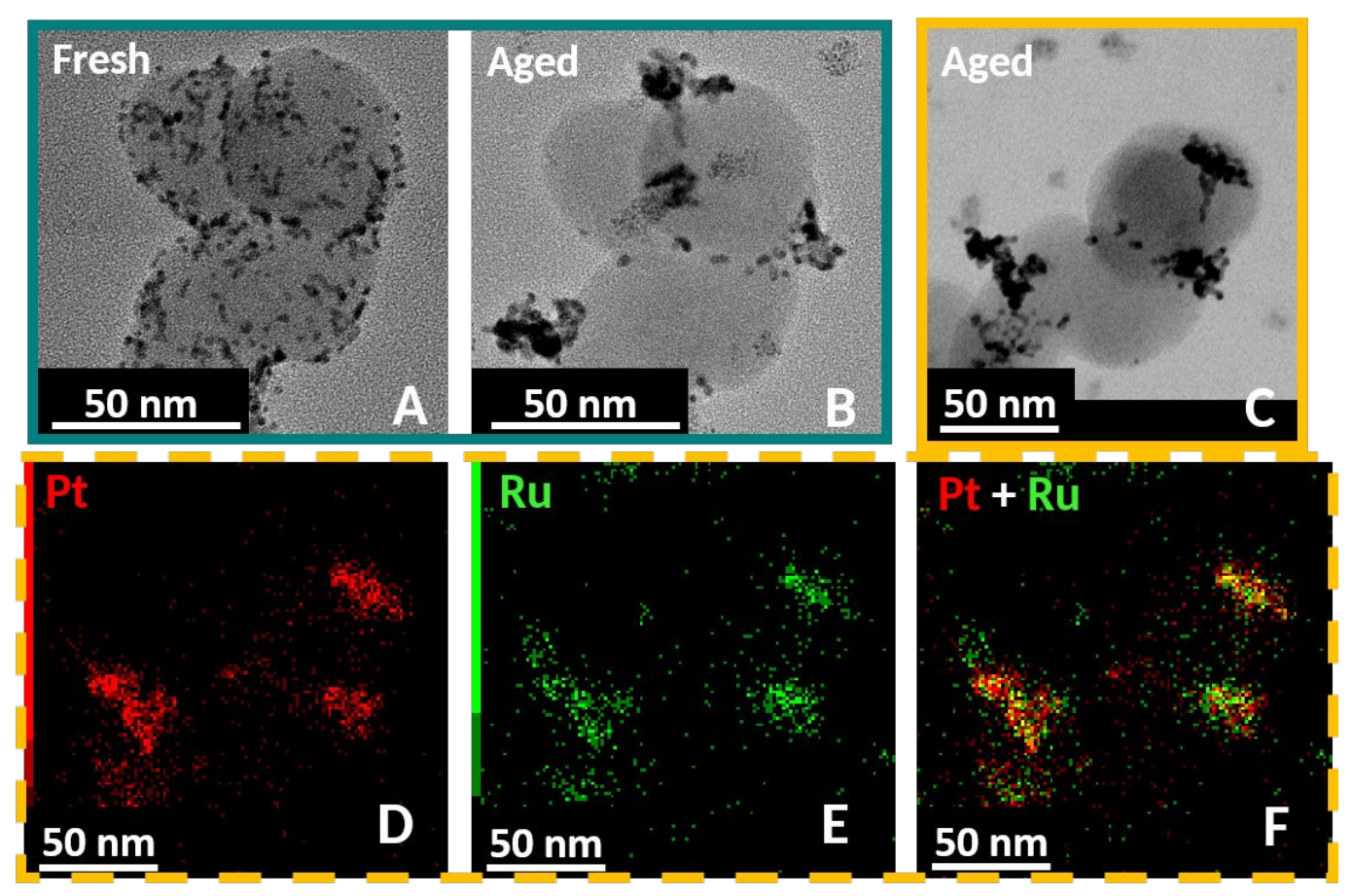

Figure 7. IL-TEM micrographs of the 10 wt. \% PtRu/C A) pre and B) post AST. C) STEM images and (D, E, F) corresponding X-EDS maps obtained on aged PtRu/C after the AST. 


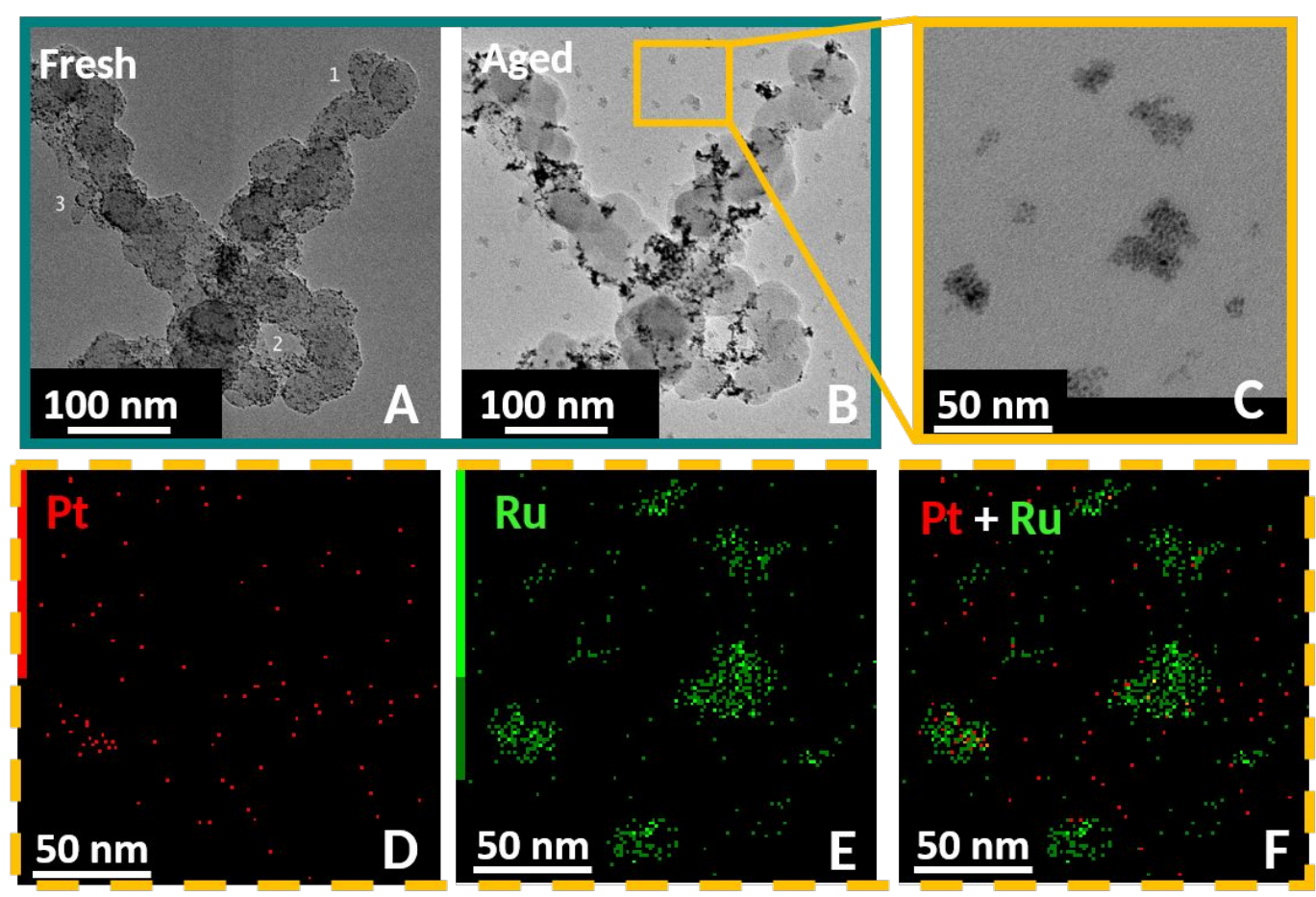

Figure 8. IL-TEM micrographs of the 10 wt. \% PtRu/C A) pre and B) post AST. C) STEM images and (D, E, F) corresponding X-EDS maps of the deposit on the TEM grid after the AST.

Comparing IL-TEM images and $\mathrm{CO}_{\text {ads }}$ stripping voltammograms reveals particularly insightful: indeed the more corroded catalysts are those for which the metal has the larger propensity to electrooxidize $\mathrm{CO}$ (Figure 6-D-H-L) in $0.1 \mathrm{M} \mathrm{NaOH}$. To quantitatively illustrate our hypotheses, the average $\mathrm{CO}_{\mathrm{ads}}$ oxidation potential $\left(\mu_{\mathrm{CO}}\right)$, first introduced by Chattot et al. ${ }^{53}$, was extracted using the first moment of the potential weight:

$$
\mu_{\mathrm{CO}}(\mathrm{V} v s . \mathrm{RHE})=\int \frac{E * I}{Q_{\mathrm{T}, \mathrm{CO}}} d E
$$

where $Q_{\mathrm{T}, \mathrm{CO}}$ is the total electric charge of the $\mathrm{CO}_{\mathrm{ads}}$ stripping voltammogram. The $\mu_{\mathrm{CO}}$ values are 0.75, 0.79 and $0.92 \mathrm{~V} v s$. RHE for $\mathrm{PtRu} / \mathrm{C}, \mathrm{Pt} / \mathrm{C}$ and $\mathrm{Pd} / \mathrm{C}$, respectively. This indicates that the more active $\mathrm{CO}_{\mathrm{ads}}$ oxidation electrocatalysts in alkaline media are respectively: $\mathrm{PtRu} / \mathrm{C}>\mathrm{Pt} / \mathrm{C}>>$ $\mathrm{Pd} / \mathrm{C}$. Strikingly, the same ranking is obtained in terms of "extent of particles detachment". 
Combining this result with the degradation monitored for the three electrocatalysts, we thus argue that the ability of an electrocatalyst to form $\mathrm{CO}_{2}$ from $\mathrm{CO}_{\text {ads }}$ determines its degradation by detachment of the metal NPs upon potential cycling in alkaline electrolyte.

Finally, the areas of the band corresponding to carbonate groups were integrated for PtRu/C and $\mathrm{Pd} / \mathrm{C}$ (Figure 9-A). The result show that, similarly to what was observed for $10 \mathrm{wt}$ \% $\mathrm{Pt} / \mathrm{C}$, carbonate species are produced at potential above $E=0.8 \mathrm{~V} v s$. RHE on PtRu/C. This is no surprise in view of the results of X-EDS elemental maps that showed that Ru atoms were dissolved during the AST, and hence did not contribute to the carbon support corrosion. In other words, the 40 wt. \% PtRu/C catalyst finally behaves as a 20 wt. \% Pt/C in terms of carbon support corrosion, which is confirmed by its intermediate situation in terms of carbonate production (Figure 9-A). On $\mathrm{Pd} / \mathrm{C}$, carbonate species are detected at $E=1.1 \mathrm{~V} v s$. RHE.

The electrical charge corresponding to each potential step was also calculated. The results, shown in Figure 9-B, reveal that the charge obtained on $\mathrm{PtRu} / \mathrm{C}$ is indeed higher to the one obtained on $\mathrm{Pt} / \mathrm{C}$ and $\mathrm{Pd} / \mathrm{C}$ because of the concomitance of $\mathrm{Ru}$ dissolution and carbonates production. We thus conclude that the degradation mechanism suggested for $\mathrm{Pt} / \mathrm{C}$ is also essentially valid for $\mathrm{PtRu} / \mathrm{C}$ and $\mathrm{Pd} / \mathrm{C}$. 


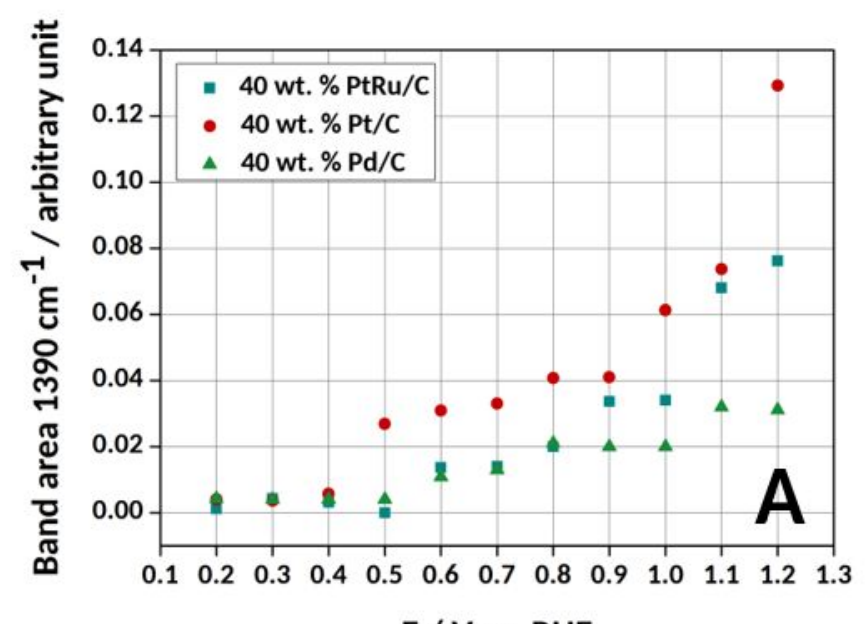

E / V vs. RHE

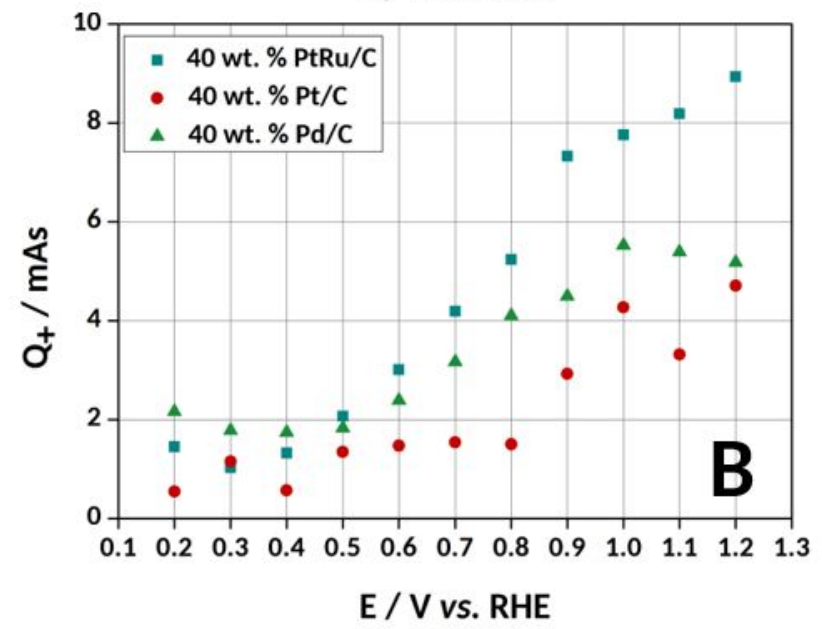

Figure 9. A) Area developed by the $1390 \mathrm{~cm}^{-1}$ band at different electrode potential on $40 \mathrm{wt}$. \% $\mathrm{PtRu} / \mathrm{C}, 40$ wt. \% Pt/C and 40 wt. \% Pd/C and B) corresponding electrical charge associated to each oxidation potential step.

\section{CONCLUSIONS}

In this work, we shed fundamental light on the origin of the detachment of Pt-based NPs occurring during an AST in alkaline media using in situ FTIR spectroscopy, ex situ XPS and ILTEM. The presence of carbonate features on the FTIR spectra implies that the degradation mechanism of Pt-based/C nanocatalysts involves the production of carbonates. Thanks to the stepwise oxidation electrochemical protocol, it was shown that carbonates are produced above $E$ 
$=0.5 \mathrm{~V} v s$. RHE for high metal wt. $\%$ and above $E=0.8 \mathrm{~V} v s$. RHE for low metal wt. \%. In addition, no carbonate features were detected on the FTIR spectra for the bare Vulcan XC72 (without Pt NPs), demonstrating that the carbonate formation is promoted by the presence of the Pt NPs at the carbon surface. As a result, one can now strongly affirm that Pt NPs assist the corrosion of the carbon support into $\mathrm{CO}_{2}$, eventually leading to the local production of solid carbonates at the vicinity of the NPs and the carbon support (at least in electrolytes compatible with metal carbonates formation, i.e. $\mathrm{NaOH}, \mathrm{LiOH}, \mathrm{KOH}$, etc.). These carbonates in turn destroy the anchoring sites between the NPs and their support, therefore leading to NP detachment. Combining FTIR spectroscopy and $\mathrm{CO}_{\text {ads }}$ stripping measurements, a straightforward relationship emerged between the ability of a material to electrooxidize $\mathrm{CO}_{\text {ads }}$ into $\mathrm{CO}_{2}$ (to form carbonates at low potential) and the extent of NP detachment. As an example, a more pronounced extent of NPs detachment is reported for $\mathrm{PtRu} / \mathrm{C}$ (with respect to $\mathrm{Pt} / \mathrm{C}$ and $\mathrm{Pd} / \mathrm{C}$ ), which is able to oxidize $\mathrm{CO}$ at lower potential than $\mathrm{Pt} / \mathrm{C}$ and $\mathrm{Pd} / \mathrm{C}$. We thus conclude that the degradation mechanism is, to some extent, similar for $\mathrm{PtRu} / \mathrm{C}, \mathrm{Pt} / \mathrm{C}$ and $\mathrm{Pd} / \mathrm{C}$, and the extent of degradation simply depend on the ability of the metal NPs to electrooxidize CO-containing surface groups present on the carbon support.

\section{ASSOCIATED CONTENT}

Supporting Information: the SI are composed of four figures

- An example of the baseline correction for the band integration of the FTIR spectra

- The FTIR spectra obtained on polycrystalline Au

- $\quad$ FTIR spectra obtained in the course of an AST consisting of 150 cycles between $E=0.1$ and $1.23 \mathrm{~V}$ vs. RHE at $100 \mathrm{mV} \mathrm{s}-1$ in $0.1 \mathrm{M} \mathrm{NaOH}$ on Vulcan XC72 
- $\mathrm{C} 1 \mathrm{~s}$ and O1s XPS spectra obtained pre and post an AST on 40 wt. \% Pt/C and Vulcan $\mathrm{XC72}$

\author{
AUTHOR INFORMATION \\ Corresponding Author \\ Clémence Lafforgue, clemence.lafforgue@lepmi.grenoble-inp.fr \\ Frédéric Maillard, frederic.maillard@lepmi.grenoble-inp.fr \\ Marian Chatenet, marian.chatenet@lepmi.grenoble-inp.fr

\section{ACKNOWLEDGMENT}

The authors thank the US Office of Naval Research Global (ONRG) for funding the thesis of Clémence Lafforgue (grant number N62909-16-1-2137). This work was performed within the framework of the Centre of Excellence of Multifunctional Architectured Materials "CEMAM" no. ANR-10-LABX-44-01. M.C. thanks the French IUF for its support.

\begin{abstract}
ABBREVIATIONS
FTIR, Fourier-Transform Infrared Spectroscopy; IL-TEM, Identical Location Transmission Electron Microscopy; PGM, Platinum Group Metal; AFC, Alkaline Fuel Cell; AWE, Alkaline Water Electrolyzer; ORR, Oxygen Reduction Reaction; OER, Oxygen Evolution Reaction; RHE, Reversible Hydrogen Electrode; ECSA, Electrochemical Surface Area; NPs, Nanoparticles; XPS, X-ray Photoelectron Spectroscopy; STEM, Scanning Transmission Electron Microscopy; XEDS, X-ray Energy Dispersive Spectroscopy; AST, Accelerated Stress Test; IPA, Isopropyl Alcohol; wt. \%, weight fraction
\end{abstract}




\section{REFERENCES}

(1) Ghoniem, A. F. Needs, Resources and Climate Change: Clean and Efficient Conversion Technologies. Prog. Energy Combust. Sci. 2011, 37, 15-51.

(2) Götz, M.; Lefebvre, J.; Mörs, F.; McDaniel Koch, A.; Graf, F.; Bajohr, S.; Reimert, R.; Kolb, T. Renewable Power-to-Gas: A Technological and Economic Review. Renew. Energy 2016, 85, 1371-1390.

(3) He, Q.; Cairns, E. J. Review-Recent Progress in Electrocatalysts for Oxygen Reduction Suitable for Alkaline Anion Exchange Membrane Fuel Cells. J. Electrochem. Soc. 2015, 162, F1504-F1539.

(4) Tarasevich, M. R.; Davydova, E. S. Nonplatinum Cathodic Catalysts for Fuel Cells with Alkaline Electrolyte (Review). Russ. J. Electrochem. 2016, 52, 193-219.

(5) Serov, A.; Zenyuk, I. V.; Arges, C. G.; Chatenet, M. Hot Topics in Alkaline Exchange Membrane Fuel Cells. J. Power Sources 2018, 375, 149-157.

(6) Gottesfeld, S.; Dekel, D. R.; Page, M.; Bae, C.; Yan, Y.; Zelenay, P.; Kim, Y. S. Anion Exchange Membrane Fuel Cells: Current Status and Remaining Challenges. J. Power Sources 2018, 375, 170-184.

(7) Marini, S.; Berrettoni, M.; Salvi, P.; Kiros, Y.; Pesenti, R.; Villa, M.; Zangari, G.; Nelli, P. Advanced Alkaline Water Electrolysis. Electrochim. Acta 2012, 82, 384-391.

(8) Schalenbach, M.; Zeradjanin, A. R.; Kasian, O.; Cherevko, S.; Mayrhofer, K. J. J. A Perspective on Low-Temperature Water Electrolysis - Challenges in Alkaline and Acidic Technology. Int. J. Electrochem. Sci. 2018, 13, 1173-1226. 
(9) Spendelow, J. S.; Wieckowski, A. Electrocatalysis of Oxygen Reduction and Small Alcohol Oxidation in Alkaline Media. Phys. Chem. Chem. Phys. 2007, 9, 2654-2675.

(10) Serov, A.; Martinez, U.; Atanassov, P. Novel Pd-In Catalysts for Alcohols Electrooxidation in Alkaline Media. Electrochem. commun. 2013, 34, 185-188.

(11) Sadiki, A.; Vo, P.; Hu, S.; Copenhaver, T. S.; Scudiero, L.; Ha, S.; Haan, J. L. Increased Electrochemical Oxidation Rate of Alcohols in Alkaline Media on Palladium Surfaces Electrochemically Modified by Antimony, Lead, and Tin. Electrochim. Acta 2014, 139, $302-307$.

(12) Ma, J.; Choudhury, N. A.; Sahai, Y. A Comprehensive Review of Direct Borohydride Fuel Cells. Renew. Sustain. Energy Rev. 2010, 14, 183-199.

(13) Serov, A.; Kwak, C. Direct Hydrazine Fuel Cells: A Review. Appl. Catal. B Environ. 2010, 98, 1-9.

(14) Serov, A.; Padilla, M.; Roy, A. J.; Atanassov, P.; Sakamoto, T.; Asazawa, K.; Tanaka, H. Anode Catalysts for Direct Hydrazine Fuel Cells: From Laboratory Test to an Electric Vehicle. Angew. Chemie - Int. Ed. 2014, 53, 10336-10339.

(15) Dekel, D. R. Review of Cell Performance in Anion Exchange Membrane Fuel Cells. J. Power Sources 2018, 375, 158-169.

(16) Varcoe, J. R.; Atanassov, P.; Dekel, D. R.; Herring, A. M.; Hickner, M. A.; Kohl, P. A.; Kucernak, A. R.; Mustain, W. E.; Nijmeijer, K.; Scott, K.; Xu, T.; Zhuang, L. AnionExchange Membranes in Electrochemical Energy Systems. Energy Environ. Sci. 2014, 7, $3135-3191$. 
(17) Amar, M.; Dekel, D. R.; Srebnik, S.; Dhara, S.; Pusara, S.; Diesendruck, C. E.; Willdorf, S.; Ash, U. The Critical Relation between Chemical Stability of Cations and Water in Anion Exchange Membrane Fuel Cells Environment. J. Power Sources 2017, 375, 351360.

(18) Dekel, D. R.; Rasin, I. G.; Page, M.; Brandon, S. Steady State and Transient Simulation of Anion Exchange Membrane Fuel Cells. J. Power Sources 2018, 375, 191-204.

(19) Chatenet, M.; Aurousseau, M.; Durand, R.; Andolfatto, F. Silver-Platinum Bimetallic Catalysts for Oxygen Cathodes in Chlor-Alkali Electrolysis - Comparison with Pure Platinum. J. Electrochem. Soc. 2003, 150, D47-D55.

(20) Olu, P. Y.; Deschamps, F.; Caldarella, G.; Chatenet, M.; Job, N. Investigation of Platinum and Palladium as Potential Anodic Catalysts for Direct Borohydride and Ammonia Borane Fuel Cells. J. Power Sources 2015, 297, 492-503.

(21) Roche, I.; Chaînet, E.; Chatenet, M.; Vondrák, J. Durability of Carbon-Supported Manganese Oxide Nanoparticles for the Oxygen Reduction Reaction (ORR) in Alkaline Medium. J. Appl. Electrochem. 2008, 38 (9), 1195-1201.

(22) Zadick, A.; Dubau, L.; Sergent, N.; Berthomé, G.; Chatenet, M. Huge Instability of Pt/C Catalysts in Alkaline Medium. ACS Catal. 2015, 5, 4819-4824.

(23) Zadick, A.; Dubau, L.; Demirci, U. B.; Chatenet, M. Effects of Pd Nanoparticle Size and Solution Reducer Strength on Pd/C Electrocatalyst Stability in Alkaline Electrolyte. $J$. Electrochem. Soc. 2016, 163, F781-F787.

(24) Lafforgue, C.; Chatenet, M.; Dubau, L.; Dekel, D. R. Accelerated Stress Test of Pt/C Nanoparticles in an Interface with an Anion-Exchange Membrane - an Identical-Location 
Transmission Electron Microscopy Study. ACS Catal. 2018, 8 (2), 1278-1286.

(25) Lafforgue, C.; Zadick, A.; Dubau, L.; Maillard, F.; Chatenet, M. Selected Review of the Degradation of Pt and Pd-Based Carbon-Supported Electrocatalysts for Alkaline Fuel Cells: Towards Mechanisms of Degradation. Fuel Cells 2018, 18, 229-238.

(26) Pourbaix, M. Atlas of Electrochemical Equilibria in Aqueous Solutions; National Association of Corrosion Engineers, Ed.; Houston, 1979.

(27) Ross, P. N.; Sokol, H. The Corrosion of Carbon Black Anodes in Alkaline Electrolyte I. Acetylene Black and the Effect of Cobalt Catalyzation. J. Electrochem. Soc. 1984, 131, $1742-1750$.

(28) Staud, N.; Ross, P. N. The Corrosion of Carbon Black Anodes in Alkaline Electrolyte II. Acetylene Black and the Effect of Oxygen Evolution Catalysts on Corrosion. $J$. Electrochem. Soc. 1986, 133, 1079-1084.

(29) Ross, P. N.; Sattler, M. The Corrosion of Carbon Black Anodes in Alkaline Electrolyte III. The Effect of Graphitization on the Corrosion Resistance of Furnace Black. J. Electrochem. Soc. 1988, 135, 1464-1470.

(30) Staud, N.; Harvey, S.; Ross, P. N. The Corrosion of Carbon Black Anodes in Alkaline Electrolyte IV. Current Efficiencies for Oxygen Evoltion from Metal Oxide-Impregnated Graphitized Furnace Blacks. J. Electrochem. Soc. 1989, 136, 3570-3576.

(31) Herrmann, C. C.; Perrault, G. G.; Pilla, A. A. Dual Reference Electrode for Electrochemical Pulse Studies. Anal. Chem. 1968, 40, 1173-1174.

(32) Garsany, Y.; Singer, I. L.; Swider-Lyons, K. E. Impact of Film Drying Procedures on RDE 
Characterization of Pt/VC Electrocatalysts. J. Electroanal. Chem. 2011, 662, 396-406.

(33) Iwasita, T.; Nart, F. In Situ Infrared Spectroscopy at Electrochemical Interfaces. Prog. Surf. Sci. 1997, 55, 271-340.

(34) Iwasita, T.; Rodes, A.; Pastor, E. Vibrational Spectroscopy of Carbonate Adsorbed on $\operatorname{Pt}(111)$ and Pt(110) Single-Crystal Electrodes. J. Electroanal. Chem. 1995, 383, 181-189.

(35) Oliver, B. G.; Davis, A. R. Vibrational Spectroscopic Studies of Aqueous Alkali Metal Bicarbonate and Carbonate Solutions. Can. J. Chem. 2006, 51, 698-702.

(36) Su, C.; Suarez, D. L. In Situ Infrared Speciation of Adsorbed Carbonate on Aluminium and Iron Oxides. Clays Clay Miner. 1997, 45, 814-825.

(37) García, G.; Rodríguez, P.; Rosca, V.; Koper, M. T. M. Fourier Transform Infrared Spectroscopy Study of CO Electro-Oxidation on Pt(111) in Alkaline Media. Langmuir 2009, 25, 13661-13666.

(38) Chang, S. C.; Ho, Y.; Weaver, M. J. Applications of Real-Time FTIR Spectroscopy to the Elucidation of Complex Electroorganic Pathways: Electrooxidation of Ethylene Glycol on Gold, Platinum, and Nickel in Alkaline Solution. J. Am. Chem. Soc. 1991, 113, 95069513.

(39) Godoi, D. R. M.; Villullas, H. M.; Zhu, F. C.; Jiang, Y. X.; Sun, S. G.; Guo, J.; Sun, L.; Chen, R. A Comparative Investigation of Metal-Support Interactions on the Catalytic Activity of Pt Nanoparticles for Ethanol Oxidation in Alkaline Medium. J. Power Sources 2016, 311, 81-90.

(40) Socrates, G. Infrared and Raman Characteristic Group Frequencies; John Wiley \& Sons 
Ltd, 2001.

(41) Kinoshita, K. Carbon Electrochemical and Physicochemical Properties; John Wiley \& sons, I., Ed.; 1988.

(42) Fanning, P. E.; Vannice, M. A. A DRIFTS Study of the Formation of Surface Groups on Carbon by Oxidation. Carbon N. Y. 1993, 31, 721-730.

(43) Zawadzki, J. Infrared Studies Of Aromatic Compounds Adsorbed Oh The Surface Of Carbon Films. Carbon N. Y. 1988, 26, 603-611.

(44) Zawadzki, J. IR Spectroscopy Studies of Oxygen Surface Compounds on Carbon. Carbon N. Y. 1978, 16, 491-497.

(45) Meldrum, B. J.; Rochester, C. H. In Situ Infrared Study of the Surface Oxidation of Activated Carbon Dispersed in Potassium Bromide. J. Chem. Soc. Faraday Trans. 1990, $86,2997-3002$.

(46) Ishizaki, C.; Marty, I. Surface Oxide Structures On A Commercial Activated Carbon. Carbon N. Y. 1981, 19, 409-412.

(47) Castanheira, L.; Dubau, L.; Mermoux, M.; Berthomé, G.; Caqué, N.; Rossinot, E.; Chatenet, M.; Maillard, F. Carbon Corrosion in Proton-Exchange Membrane Fuel Cells: From Model Experiments to Real-Life Operation in Membrane Electrode Assemblies. ACS Catal. 2014, 4, 2258-2267.

(48) Castanheira, L.; Silva, W. O.; Lima, F. H. B.; Crisci, A.; Dubau, L.; Maillard, F. Carbon Corrosion in Proton-Exchange Membrane Fuel Cells: Effect of the Carbon Structure, the Degradation Protocol, and the Gas Atmosphere. ACS Catal. 2015, 5, 2184-2194. 
(49) Maillard, F.; Bonnefont, A.; Micoud, F. An EC-FTIR Study on the Catalytic Role of Pt in Carbon Corrosion. Electrochem. commun. 2011, 13, 1109-1111.

(50) Maillard, F.; Savinova, E. R.; Simonov, P. A.; Zaikovskii, V. I.; Stimming, U. Infrared Spectroscopic Study of CO Adsorption and Electro-Oxidation on Carbon-Supported Pt Nanoparticles: Interparticle versus Intraparticle Heterogeneity. J. Phys. Chem. B 2004, $108,17893-17904$.

(51) Štrbac, S.; Adžić, R. R. The Influence of OH- Chemisorption on the Catalytic Properties of Gold Single Crystal Surfaces for Oxygen Reduction in Alkaline Solutions. J. Electroanal. Chem. 1996, 403, 169-181.

(52) Yi, Y.; Weinberg, G.; Prenzel, M.; Greiner, M.; Heumann, S.; Becker, S.; Schlögl, R. Electrochemical Corrosion of a Glassy Carbon Electrode. Catal. Today 2017, 295, 32-40.

(53) Chattot, R.; Asset, T.; Bordet, P.; Drnec, J.; Dubau, L.; Maillard, F. Beyond Strain and Ligand Effects: Microstrain-Induced Enhancement of the Oxygen Reduction Reaction Kinetics on Various PtNi/C Nanostructures. ACS Catal. 2017, 7, 398-408. 